\title{
WATCHING
}

\section{WHILE BLACK}


This page intentionally left blank 


\section{WATCHING WHILE BLACK}

Centering the Television

of Black Audiences

EDITED BY

BERETTA E. SMITH-SHOMADE 
Watching while black : centering the television of black audiences / edited by Beretta E. Smith-Shomade.

p. $\mathrm{cm}$.

Includes bibliographical references and index.

ISBN 978-0-8I35-5387-o (hardcover : alk. paper) — ISBN 978-0-8I35-5386-3

(pbk. : alk. paper) — ISBN 978-0-8135-5388-7 (e-book)

I. African Americans on television. 2. African American television viewers.

3. Television broadcasting-Social aspects-United States. I. Smith-Shomade, Beretta E., 1965-

PNi992.8.A34W $38 \quad 2012$

791.45'08996073-dc23

2012005040

A British Cataloging-in-Publication record for this book is available from the British Library.

This collection copyright (C) 2012 by Rutgers, The State University

Individual chapters copyright (C) 2012 in the names of their authors

All rights reserved

No part of this book may be reproduced or utilized in any form or by any means, electronic or mechanical, or by any information storage and retrieval system, without written permission from the publisher. Please contact Rutgers University Press, I06 Somerset Street, New Brunswick, NJ 0890I. The only exception to this prohibition is "fair use" as defined by U.S. copyright law.

Visit our website: http:/ / rutgerspress.rutgers.edu

Manufactured in the United States of America 
For Teshome Gabriel

Thank you 
This page intentionally left blank 